\title{
PASSAGE OF SODIUM INTO THE UTERINE LUMEN OF THE RAT DURING THE SEXUAL CYCLE AND UNDER THE INFLUENCE OF STEROIDAL HORMONES
}

\author{
P. B. MARLEY* AND J. M. ROBSON $\dagger$ \\ Department of Pharmacology, \\ Guy's Hospital Medical School, London, S.E.1
}

(Received 29th September 1969, revised 4th December 1970)

\begin{abstract}
Summary. The rate of passage of intravenously injected $\left[{ }^{22} \mathrm{Na}\right]$ sodium into the uterine lumen of the rat has been measured in vivo as a means of examining changes in the uterine luminal environment. The rate varied significantly at different stages of the oestrous cycle and during the first 10 days of pregnancy and pseudopregnancy. Some of these variations were probably the result of changes in the levels of circulating steroid hormones since variations of a similar type could be produced in ovariectomized rats given physiological amounts of oestrogen or oestrogen plus progesterone. The other variations in the rate of passage appear to be due to changes brought about by the process of implantation and the growth of the implantation site.

The comparatively slow rate of passage of $\left[{ }^{22} \mathrm{Na}\right]$ sodium into the lumen in these experiments indicates that there is a considerable barrier to the passage of sodium between the extracellular fluid and the uterine luminal fluid.
\end{abstract}

\section{INTRODUCTION}

In the present work, an attempt has been made to present a new approach to the examination of the uterine luminal environment during the oestrous cycle and under the influence of oestrogen and progesterone. The rate of passage of $\left[{ }^{22} \mathrm{Na}\right]$ sodium into the uterine lumen of the rat has been measured to see whether it changes under these conditions.

This technique could be applied to many ions, but it has been confined initially to sodium as this is the major cation in uterine and blastocyst fluids. In one experiment, however, $\left[{ }^{131} \mathrm{I}\right]$ iodoantipyrine was also used.

\section{METHOD}

Albino Wistar rats bred in the Animal House at Guy's Hospital Medical School were used. The females were nulliparous, weighed 200 to $300 \mathrm{~g}$ and had cycle lengths of 4 days before the experiments. Pseudopregnancy was induced

* Present address: Department of Pharmacology, The School of Pharmacy, University of London.

$\uparrow$ Present address: Department of Pharmacology, Chelsea College, University of London. 
by mating with vasectomized males implanted with testosterone. The day of mating was called Day 1.

Each rat was used for only one perfusion experiment. The perfusions in the normal non-pregnant rats were performed in conscious animals following operation carried out under ether anaesthesia, whereas the perfusions in ovariectomized, pregnant and pseudopregnant rats were performed under pentobarbitone sodium ( $25 \mathrm{mg} /$ intraperitoneally) anaesthesia.

The following procedure was adopted for the perfusion of the uterus. The uterus was exposed at the ovarian and cervical ends through small abdominal incisions. Cotton ligatures were placed around the ends of the uterus, being sewn between the mesometrial blood vessels since this avoided damage and prevented their occlusion when the ligatures were tied. Small incisions were made antimesometrially through the wall of the uterus at both ends of each horn and about $2 \mathrm{~mm}$ of the tip of each cannula (approximately $1 \mathrm{~mm}$ diameter), was pushed into the lumen and the ligatures were then tied.

Each cannula was attached to silicone rubber tubing, the free part of which issued from the peritoneal cavity and the abdominal muscles were closed around it. Where the perfusions were performed in conscious rats, the tubes were brought out at the dorsal side of the neck, and the rats were restrained in adjustable cages for the duration of the perfusions. These procedures were unnecessary for the perfusions performed under anaesthesia, but the body temperature of the rats had to be maintained at $37^{\circ} \mathrm{C}$.

The uterine lumen was perfused with a Locke solution containing $9.2 \mathrm{~g}$ $\mathrm{NaCl}, 0.42 \mathrm{~g} \mathrm{KCl}, 0.24 \mathrm{~g} \mathrm{CaCl}_{2}, 0.15 \mathrm{~g} \mathrm{NaHCO}_{3}$ and $1.0 \mathrm{~g}$ glucose per litre. The pressure head of the perfusion system was achieved by passing compressed air into the perfusion fluid reservoir. The air pressure in the reservoir was set at $35 \mathrm{~mm} \mathrm{Hg}$ above atmospheric pressure by adjustment of an air leak. Thus, the perfusion pressure within the uterine lumen never exceeded $35 \mathrm{~mm} \mathrm{Hg}$ and was usually much lower during perfusion. The Locke solution was warmed to $37^{\circ} \mathrm{C}$ and was perfused through the lumen at a rate of $0.4 \mathrm{ml} / \mathrm{min}$ (the rate was not critical). The fluid was collected in disposable test tubes.

An injection of 4 to $10 \mu \mathrm{c}\left[{ }^{22} \mathrm{Na}\right] \mathrm{Cl}$ was given into a tail vein and the uterine perfusion was begun about 25 min later. Within this time, the ${ }^{22} \mathrm{Na}$ was distributed throughout the extracellular water since, thereafter, the ${ }^{22} \mathrm{Na}$ content of the blood decreased only slowly compared with its initial decrease, a fact established in an initial experiment by monitoring the radioactivity of blood passing through a coil of polythene tubing connected between a carotid artery and femoral vein.

The uterine lumen was perfused for at least $5 \mathrm{~min}$ before any samples were collected in order to wash out any ${ }^{22} \mathrm{Na}$ which had passed into the lumen. The perfusate collected 30 to $60 \mathrm{~min}$ after the injection was used to determine the rate of passage of ${ }^{22} \mathrm{Na}$ into the lumen. The total radioactivity present in the perfusate was expressed as a percentage of the radioactivity in an arbitrary volume of $1 \mathrm{ml}$ of plasma, a blood sample being taken from the heart at the end of the perfusion.

Radioactivity was measured with a Dynatron/Ekco well-crystal scintillation counter using a sample volume of $2 \mathrm{ml}$. The $\left[{ }^{22} \mathrm{Na}\right] \mathrm{Cl}$ and $\left[{ }^{131} \mathrm{I}\right] 4$-iodoanti- 
pyrine were obtained from the Radiochemical Centre, Amersham. The steroid hormones were dissolved in arachis oil and injected subcutaneously.

\section{RESULTS}

Rate of passage of ${ }^{22} \mathrm{Na}$ into pro-oestrous fluid

The rate of passage of ${ }^{22} \mathrm{Na}$ into the fluid contained within the uterine lumen

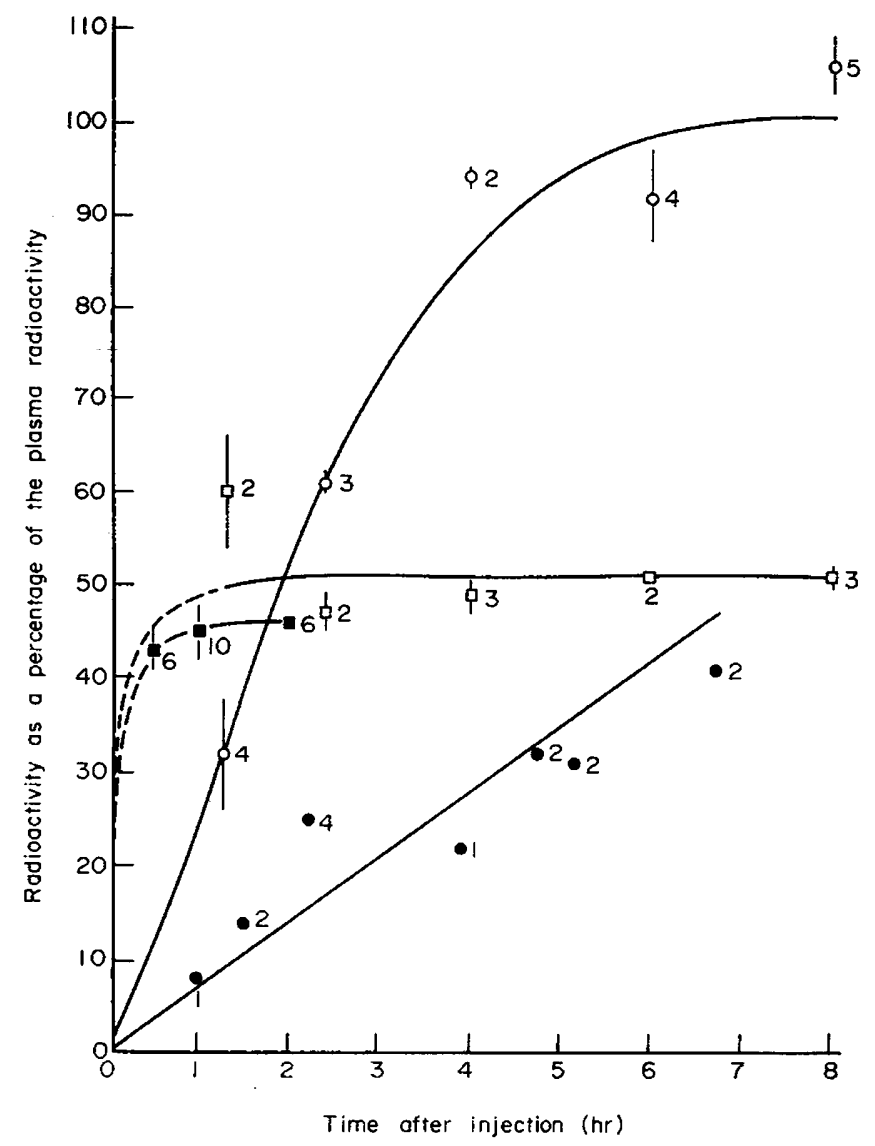

Text-FIG. 1. The rate of equilibration of $\left[{ }^{22} \mathrm{Na}\right]$ sodium with pro-oestrous fluid filling the uterine lumen (O) and with uterine tissue (D) compared with the rate of equilibration of [ $\left.{ }^{131} 1\right]$-iodoantipyrine with pro-oestrous fluid $(O)$ and with uterine tissue $(\square)$ under similar conditions. Each point is the mean \pm S.E. value of the number of observations shown.

at pro-oestrus was studied first. Radioactive sodium was injected intravenously into conscious rats and the uterine fluid was removed after various time intervals.

Equilibration of ${ }^{22} \mathrm{Na}$ with pro-oestrous fluid was slow compared with its rate of equilibration with the tissues of the uterus, where equilibration was almost complete within $30 \mathrm{~min}$ of the injection (Text-fig. 1). For example, $400 \mathrm{~min}$ after the injection, the fluid contained $40 \%$ of the ${ }^{22} \mathrm{Na}$ content of an 
equal volume of plasma. As the ${ }^{22} \mathrm{Na}$ content at full equilibration would have been about $83 \%$, allowing for the fact that uterine fluid contains less sodium than does plasma (Howard \& De Feo, 1959), only about $50 \%$ equilibration had occurred within 400 min.

It was found that $\left[{ }^{131} \mathrm{I}\right]$ iodoantipyrine, which equilibrates with total body water and was used as a control in this experiment, equilibrated with uterine fluid at a faster rate than ${ }^{22} \mathrm{Na}$, the process being virtually complete after $4 \mathrm{hr}$ (Text-fig. 1).

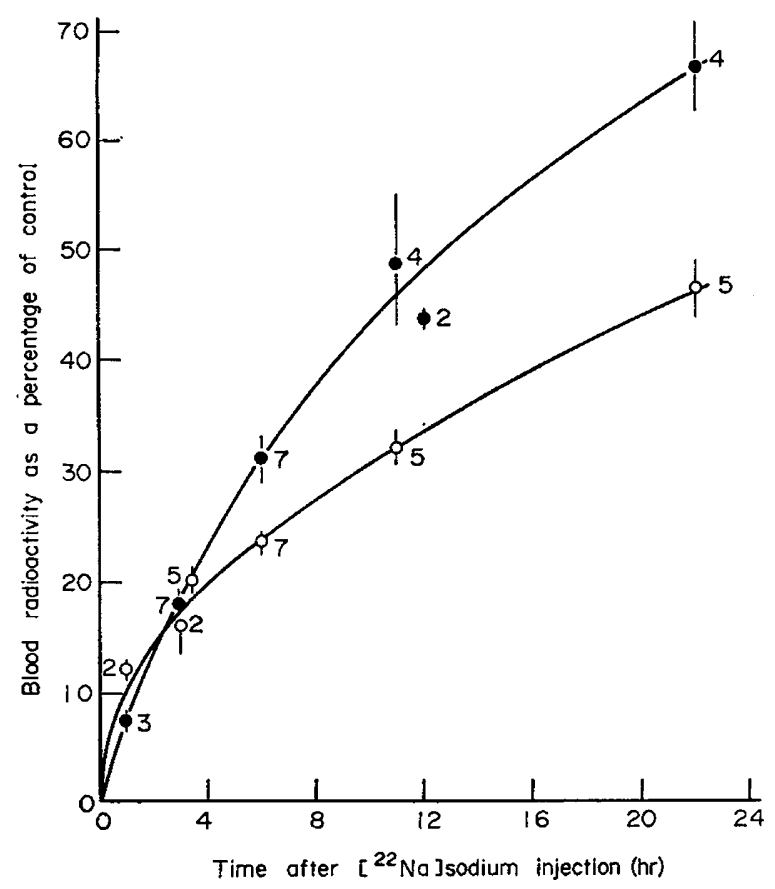

TEXT-FIG. 2. The rate of absorption of $\left[{ }^{22} \mathrm{Na}\right]$ sodium from the uterine lumen of rats at the oestrous (O) and dioestrous $(O)$ stages of the cycle at the commencement of the experiment. The blood radioactivity in the rats injected intraluminally with $\left[{ }^{22} \mathrm{Na}\right]$ sodium is expressed as a percentage of the blood radioactivity in control rats injected intraperitoneally with the same amount of $\left[{ }^{22} \mathrm{Na}\right]$ sodium. Each point is the mean \pm S.E. value of a number of observations, as shown. Values at 6,11 to 12 and $22 \mathrm{hr}$ are significantly different $(P<0.02)$ comparing the two stages.

\section{Rate of absorption of ${ }^{22} \mathrm{Na}$ from the uterine lumen}

With the uterus ligated at the cervix and at the site of injection at the uterotubal junction to prevent any leakage, ${ }^{22} \mathrm{Na}$ injected into the uterine lumen passed only slowly into the general circulation. For example, $22 \mathrm{hr}$ after the injection, the blood radioactivity was 34 to $54 \%$ lower than in rats where ${ }^{22} \mathrm{Na}$ had been injected intraperitoneally (Text-fig. 2). The ${ }^{22} \mathrm{Na}$ unaccounted for was shown to be present within the uterus.

The rate of absorption of ${ }^{22} \mathrm{Na}$ from the uterine lumen was significantly slower in those rats which were injected on the day of dioestrus than in those injected on the day of oestrus, judging by the blood radioactivity (Text-fig. 2). 
Rate of passage of ${ }^{22} \mathrm{Na}$ into the perfused uterine lumen

At most stages of the cycle, it was difficult to obtain samples of uterine fluid and, therefore, the horns were perfused with Locke solution to wash out any ${ }^{22} \mathrm{Na}$ which passed into the lumen. Light microscopical studies revealed no apparent damage due to the perfusion. However, the results obtained by perfusion may overestimate the normal rate since, at pro-oestrus, the rate of passage of ${ }^{22} \mathrm{Na}$ into the lumen of horns filled naturally with fluid appears to be twice as slow as in the perfused horns, as can be seen from the following figures. The radioactivity of pro-oestrous fluid increased by $7 \%$ per $\mathrm{hr}$ when expressed in terms of the radioactivity in an equivalent volume of plasma (average vol.

\section{TABLE 1}

THE RATE OF PASSAGE OF $\left[{ }^{22} \mathrm{Na}\right.$ ] SODIUM INTO THE PERFUSED UTERINE LUMEN, IN RATS AT VARIOUS STAGES OF THE OESTROUS CYGLE AND IN OVARIECTOMIZED RATS TREATED WITH OESTROGEN

\begin{tabular}{|c|c|c|c|c|}
\hline \multirow{2}{*}{ Stage or treatment } & \multirow{2}{*}{$\begin{array}{l}\text { No. of } \\
\text { horns } \\
\text { perfused }\end{array}$} & \multicolumn{3}{|c|}{${ }^{22} \mathcal{N} a$ content of perfusate $\dagger$} \\
\hline & & Mean $\pm S . E$. & Ref. no. & Significance $\ddagger$ \\
\hline $\begin{array}{l}\text { Pro-oestrus } \\
\text { Oestrus } \\
\text { Metoestrus } \\
\text { Dioestrus }\end{array}$ & $\begin{array}{l}3 \\
5 \\
4 \\
6\end{array}$ & $\begin{array}{l}1 \cdot 46 \pm 0.24 \\
0.77 \pm 0.13 \\
2 \cdot 83 \pm 0.17 \\
4 \cdot 14 \pm 0.73\end{array}$ & $\begin{array}{l}(1) \\
(2) \\
(3) \\
(4)\end{array}$ & $\begin{array}{l}* *(3,4) \\
*(1) * * *(3,4) \\
* *(3)\end{array}$ \\
\hline $\begin{array}{l}\text { Ovariectomized and injected } 3 \text { weeks later } \\
\text { with } 1 \text { or } 10 \mu \text { g oestradiol monobenzoate } / \\
\text { day } \times 5 \text { days, and perfused on } 5 \text { th day }\end{array}$ & 6 & $1.00 \pm 0.38$ & (5) & N.S. $(1,2) * *(3,4)$ \\
\hline $\begin{array}{l}\text { Ovariectomized and primed } 3 \text { weeks later } \\
\text { with } 10 \mu \mathrm{g} \text { oestradiol } 5 \text { days before per- } \\
\text { fusion, followed by: }\end{array}$ & & & & \\
\hline No further treatment & 10 & $5 \cdot 04 \pm 0 \cdot 43$ & (6) & \\
\hline $10 \mu \mathrm{g}$ oestradiol $6 \mathrm{hr}$ before perfusion & 8 & $5 \cdot 38 \pm 0 \cdot 81$ & (7) & N.S. (6) \\
\hline $10 \mu \mathrm{g}$ oestradiol $18 \mathrm{hr}$ before perfusion & 8 & $2 \cdot 70 \pm 0 \cdot 25$ & (8) & $* * *(6) *(7,9)$ \\
\hline $\begin{array}{l}10 \mu \mathrm{g} \text { oestradiol } 44 \text { to } 50 \mathrm{hr} \text { before per- } \\
\text { fusion }\end{array}$ & 12 & $4 \cdot 02 \pm 0 \cdot 40$ & (9) & N.S. $(6)$ \\
\hline
\end{tabular}

$\dagger$ Counts/min per 30 -min perfusate sample $\times 100$

Counts/min per $\mathrm{ml}$ plasma from same rat

$\ddagger$ Levels of significance, compared with the mean corresponding to the ref. no. given, ${ }^{* * *} P<0 \cdot 001$; $* * P<0.01 ; * P<0.05$; N.S. not significant.

$0.2 \mathrm{ml}$, Text-fig. 1). Expressed in terms of $1 \mathrm{ml}$ plasma, this is equivalent to an increase in radioactivity in the lumen of $1.4 \%$ per $\mathrm{hr}$, whereas $1.46 \%$ of the radioactivity in $1 \mathrm{ml}$ plasma was recovered in $30 \mathrm{~min}$ in the perfusion experiments (Table 1).

(i) Effect of stage of the oestrous cycle. These experiments were performed in conscious rats. For the major part of the perfusion, the pressure of the fluid as it entered the uterine lumen ranged between 0 to $5 \mathrm{~mm} \mathrm{Hg}$. As the uterus contracted rhythmically throughout the perfusion, there was a greater resistance to perfusion and the pressure increased to, though not above, $15 \mathrm{~mm} \mathrm{Hg}$.

The amount of ${ }^{22} \mathrm{Na}$ washed from the uterine lumen varied significantly at different stages of the oestrous cycle. The perfusate contained the least at 
oestrus and the most at dioestrus, the values at pro-oestrus and metoestrus being intermediate (Table 1).

(ii) Effect of oestrogen in ovariectomized rats. Three weeks after ovariectomy, rats were injected with oestradiol monobenzoate daily for 5 days (three with $1 \mu \mathrm{g}$ and three with $10 \mu \mathrm{g} /$ day). The uterine horns were perfused on the 5th day of oestrogen treatment, without anaesthesia. The vaginal smears were cornified on that day.

The rate of passage of ${ }^{22} \mathrm{Na}$ into the uterine lumen was not significantly different in these rats from the rates at the oestrous and pro-oestrous stages, but it was significantly lower than those at the metoestrous and dioestrous stages (Table 1).

In the next experiment, the effect of a single dose of oestradiol was investigated in rats ovariectomized 3 weeks before perfusion. Since the uterine horns were too small to be perfused successfully so long after ovariectomy, the rats were given a priming dose of $10 \mu \mathrm{g}$ oestradiol 5 days before the perfusion to initiate growth. On the day of perfusion, the rats were either given no further treatment (controls) or were injected with $10 \mu \mathrm{g}$ oestradiol 6,18 or 44 to $50 \mathrm{hr}$ before the perfusion. During the perfusion, the rats were anaesthetized with pentobarbitone sodium.

The rate of passage of ${ }^{22} \mathrm{Na}$ into the uterine lumen was significantly lower in rats perfused $18 \mathrm{hr}$ after the oestradiol injection than in the control rats, but the rate was not significantly different 6 , or 44 to $50 \mathrm{hr}$ after treatment (Table 1). By contrast, oestradiol produced an increase in uterine weight both $18 \mathrm{hr}$ (118 $\pm 7 \mathrm{mg} / \mathrm{horn}, \mathrm{mean} \pm \mathrm{S}$.E.) and 44 to $50 \mathrm{hr}$ after the injection $(119 \pm 4)$ since these horns were significantly heavier $(P<0.002)$ than those of the controls $(80 \pm 7)$ or those of the 6-hr group $(86 \pm 3)$.

(iii) Effect of stage of pregnancy and pseudopregnancy. There was a higher resistance to perfusion at these stages. The lowest pressures $(10$ to $25 \mathrm{~mm} \mathrm{Hg}$ ) were found in anaesthetized rats, so these were used in preference to conscious rats. However, there was no evidence to suggest that the higher perfusion pressures affected the rate of passage of ${ }^{22} \mathrm{Na}$ into the lumen. For example, there was no association between the amount of radioactivity in the perfusate and the perfusion pressure, which could vary by 10 or $15 \mathrm{~mm} \mathrm{Hg}$ in different rats at the same stage. When the pressure was maintained at various levels by occluding the flow from the uterine lumen of a rat at dioestrus, no significant effect was seen with pressures of 15 and $30 \mathrm{~mm} \mathrm{Hg}$, i.e. the range used, although a significant decrease in rate occurred at $35 \mathrm{~mm} \mathrm{Hg}(33 \%, P<0.05)$.

The amount of ${ }^{22} \mathrm{Na}$ washed from the uterine lumen was the same on Days 4 and 5 of pregnancy and pseudopregnancy as it was at dioestrus (Table 2). Between 21.00 and 24.00 hours on Day 5, however, the uterine perfusates contained about twice as much ${ }^{22} \mathrm{Na}$ as at the previous times. In the pseudopregnant rats, this situation remained unchanged until Day 10 (the last day investigated) but, in the pregnant rats, the ${ }^{22} \mathrm{Na}$ content decreased on the day of implantation (Day 6) and, thereafter, increased so that by Day 8 it was significantly greater than that in the pseudopregnant rats (Table 2).

(iv) Effect of progesterone alone or in combination with oestrogen. Experiments were carried out to determine whether the increase in the rate of passage of ${ }^{22} \mathrm{Na}$ 
into the uterine lumen on the evening of Day 5 of pregnancy and of pseudopregnancy was dependent on the hormonal levels of progesterone and oestrogen at that time.

Pseudopregnant rats were ovariectomized on Day 3 and were given immediately, and on subsequent days, $4 \mathrm{mg}$ progesterone subcutaneously. Half of these rats were given $1 \mu \mathrm{g}$ oestradiol subcutaneously at 17.00 hours on Day 4 , a time which corresponds to the period of 'oestrogen surge' before implantation (Shelesnyak, 1960). The uterine horns were perfused on Day 6.

The rate of passage of ${ }^{22} \mathrm{Na}$ into the uterine lumen was different in the two

\section{TABLE 2}

The RATE OF PASSAge of $\left[{ }^{22} \mathrm{Na}\right]$ SODIUM INTO THE PERfuSEd UTERINE LUMEN, IN RATS AT VARIOUS STAGES OF PREGNANCX OR PSEUDOPREGNANGY

\begin{tabular}{|c|c|c|c|c|}
\hline \multirow{2}{*}{ Stage or treatment } & \multirow{2}{*}{$\begin{array}{l}\text { No. of } \\
\text { horns } \\
\text { perfused }\end{array}$} & \multicolumn{3}{|c|}{${ }^{22} \mathcal{N a}$ content of perfusate $\dagger$} \\
\hline & & Mean \pm S.E. & Ref. no. & Significance $\ddagger$ \\
\hline $\begin{aligned} & \text { Pregnant Day } 4 \\
& 5 \\
& 5 \$ \\
& 6 \\
& 7 \\
& 8\end{aligned}$ & $\begin{array}{l}6 \\
6 \\
8 \\
8 \\
4 \\
9\end{array}$ & $\begin{array}{r}3 \cdot 54 \pm 0 \cdot 36 \\
4 \cdot 89 \pm 0 \cdot 53 \\
9 \cdot 39 \pm 1 \cdot 13 \\
4.89 \pm 0 \cdot 64 \\
13 \cdot 93 \pm 1 \cdot 52 \\
19 \cdot 50 \pm 1 \cdot 76\end{array}$ & $\begin{array}{l}(1) \\
(2) \\
(3) \\
(4) \\
(5) \\
(6)\end{array}$ & $\begin{array}{l}\text { N.S. }(4,7,8) \\
* * *(3,5,6) \\
* *(2,4) \text { N.S. }(9) \\
* * *(3,5,6,10) \\
* * *(11)\end{array}$ \\
\hline $\begin{array}{r}\text { Pseudopregnant Day } 4 \\
5 \\
5 \$ \\
6 \\
8 \\
9 \\
10\end{array}$ & $\begin{array}{l}6 \\
8 \\
6 \\
9 \\
9 \\
6 \\
6 \\
2\end{array}$ & $\begin{array}{r}4 \cdot 91 \pm 0.90 \\
3 \cdot 75 \pm 0 \cdot 34 \\
10 \cdot 63 \pm 0 \cdot 77 \\
11 \cdot 14 \pm 1 \cdot 09 \\
10 \cdot 84 \pm 1 \cdot 48 \\
8.94 \pm 1 \cdot 82 \\
13 \cdot 63 \pm 2 \cdot 16\end{array}$ & $\begin{array}{r}(7) \\
(8) \\
(9) \\
(10) \\
(11) \\
(12) \\
(13)\end{array}$ & $\begin{array}{l}* *(9,10,11,13) \\
\text { N.S. (3) } \\
* * *(4) \\
* * *(6) \\
* \quad(8)\end{array}$ \\
\hline $\begin{array}{l}\text { Ovariectomized on Day } 3 \text { of } \\
\text { pseudopregnancy, given } 4 \mathrm{mg} \\
\text { progesterone daily and perfused } \\
\text { on Day } 6\end{array}$ & & & & \\
\hline $\begin{array}{l}\text { No other treatment } \\
1 \mu \mathrm{g} \text { oestradiol } 17.00 \text { hours Day } 4\end{array}$ & $\begin{array}{l}10 \\
10\end{array}$ & $\begin{array}{r}6 \cdot 60 \pm 0 \cdot 33 \\
21 \cdot 19 \pm 2 \cdot 12\end{array}$ & (14) & $\begin{array}{l}* * *(8,10) \\
* * *(10,14)\end{array}$ \\
\hline
\end{tabular}

$\dagger$ Counts/min per 30-min perfusate sample $\times 100$

Counts/min/ml plasma from same rat

$\ddagger$ Levels of significance, compared with the mean corresponding to the ref. no. given, ${ }^{* * *} P<0 \cdot 001$; ${ }^{* *} P<0.01 ;{ }^{*} P<0.05 ;$ N. S. not significant.

$\$$ Perfused between 21.00 and 24.00 hours; otherwise between 10.00 and 17.00 hours.

groups, being almost three times as great in the group treated with oestrogen plus progesterone (Table 2). In neither case was the rate the same as in the intact pseudopregnant rats on Day 6. These results indicate that oestrogen can increase the rate of passage of ${ }^{22} \mathrm{Na}$ into the uterine lumen when the uterus is under progesterone dominance.

(v) Comparison between pregnant and pseudopregnant horns in the same rat on Day 8. The rate of passage of ${ }^{22} \mathrm{Na}$ into the uterine lumen on Day 8 was significantly greater in pregnant than in pseudopregnant rats (Table 2). As this could have been due to differences in the levels of oestrogen and progesterone, as indicated by the results above, the following experiment was performed.

Rats were mated and one horn in each animal was made pseudopregnant by 
ligating and cutting the oviduct at the utero-tubal junction on Day 3, thus preventing ova from entering the uterus. The horns of four such animals were perfused on Day 8. The rate of passage of ${ }^{22} \mathrm{Na}$ into the ligated pseudopregnant horns $(10 \cdot 27 \pm 2 \cdot 40)$ was the same as that in intact pseudopregnant rats and different from that in pregnant rats on Day 8 (Table 2). Thus, there was no evidence to suggest that the circulating steroid hormone levels were different on Day 8 of pregnancy and pseudopregnancy.

\section{DISGUSSION}

There are no other data available on the rates of equilibrium of isotopes with uterine fluid apart from those in the rabbit, where equilibration appears to be complete within 45 min (Lutwak-Mann, Boursnell \& Bennett, 1960).

Data obtained in the rat show that the rate of passage of ${ }^{22} \mathrm{Na}$ into the lumen is slow, and varies during the oestrous cycle and early pregnancy and pseudopregnancy. This indicates that, like other secretions of the anatomical extracellular water (Manery, 1954), uterine fluid is separated from the physiological extracellular water by a diffusion barrier which probably maintains the differences in composition between it and plasma (Howard \& DeFeo, 1959; Ringler, 1961). In addition, it suggests that the nature of the barrier may change during the cycle.

The slow rate of passage of sodium into or out of the uterine lumen at prooestrus and oestrus and in ovariectomized rats treated with oestrogen suggests that the barrier to diffusion may be increased by oestrogen, but a number of factors could bring this about. It is paradoxical that at pro-oestrus, when the rate of passage of sodium is almost at its lowest, the rate of secretion of uterine fluid should be at its greatest, and sodium relative to other ions should be in greatest concentration in luminal washes (Heap, 1962).

Oestrogen may hinder diffusion by increasing the thickness of the endometrial epithelium (Hooker, 1945; Davis \& Alden, 1959; Elftman, 1963) and the granular secretion which covers it (Fuxe \& Nilsson, 1963). Others have interpreted the actions of oestrogen on diffusion across the vagina in terms of changes in the cells lining the vaginal epithelium (Gregoire, Driscoll \& Adams, 1967; Gregoire, Driscoll, Adams \& Rakoff, 1967). Alternatively, oestrogen might decrease the rate by reducing blood flow in all or part of the uterus perhaps by a secondary effect due to oedema. Although oestrogen causes hyperaemia (Hechter, Krohn \& Harris, 1942; Williams, 1948; Reynolds, 1949; Young, 1952) and can increase the blood volume three-fold (Cole, 1950), blood flow per gram uterine tissue is lower at oestrus than at dioestrus (Kopin \& Wurtman, 1963).

By contrast with the effects of oestrogen in non-pregnant rats, experiments in pregnant and pseudopregnant or in progesterone-treated rats show that oestrogen can increase the rate of passage of sodium into the lumen under certain circumstances. As the dose of oestrogen used in the latter experiment was one tenth that used in the former, it is possible that oestrogen has a different effect depending on its concentration. However, a more likely explanation is that oestrogen has a different effect when acting in conjunction with progesterone. 
This may explain why oestrogen early in pregnancy has an effect which differs from that seen a few days later in the equilibration experiments of LutwakMann et al. (1960) in the rabbit.

The mechanism by which oestrogen under these circumstances can increase the rate is not known. Changes do occur in the endometrium, for example in the epithelial lining (Allen, 1931) and in the blood supply (Williams, 1948), but these are not in sequence with the recorded changes in rate. If oestrogen is secreted only once between Days 4 to 10 of pseudopregnancy, i.e. as a surge on the evening of Day 4 yet its consequences in pseudopregnant rats last from the evening of Day 5 until Day 10, oestrogen must bring about a fundamental change in the uterus.

In the mouse, the uterine lumen closes at the time of implantation, as microvilli bordering the surface cells of the epithelium on adjacent sides enmesh and lock together (Potts, 1966) and this may be initiated by oestrogen. In pseudopregnant rats, the uterine lumen appears to close between Days 5 and 6 since, following perfusion, the microvilli are intact on Day 5 but are torn on Day 6 (Marley \& Potts, unpublished). As the rate increases at precisely the time when the microvilli become torn, the two may be associated. Whether this accounts for the elevated rate on other days up to Day 10 of pseudopregnancy cannot be determined until it is known for how long the uterine lumen remains closed.

The low rate on Day 6 in pregnant as compared with pseudopregnant rats appears to be associated with decidual cell formation since it occurs in pseudopregnant rats in which a decidual cell reaction is induced with arachis oil (Marley \& Robson, unpublished). The oedema which accompanies decidual cell initiation may reduce blood flow in the endometrium and thus lower the diffusion rate.

The present results do not preclude the possibility that the rate of passage of sodium into the lumen reflects the suitability of the uterine lumen for the preimplantation zygote. Thus, the rate of passage is similar at a number of different stages at which morulae and blastocysts can survive in the lumen, i.e. dioestrus, Days 4 and 5 of pregnancy and pseudopregnancy, and in ovariectomized rats. Furthermore, oestrogen can change the rate of passage of sodium, and causes the death of morulae and blastocysts when they are unable to implant (Dickmann, 1967, 1969).

\section{AGKNOWLEDGMENTS}

This work was in part supported by grants from The Population Council, New York and The Medical Research Council, whose help we gratefully acknowledge.

\section{REFERENGES}

Allen, W. M. (1931) 1. Cyclical alterations of the endometrium of the rat during the normal cycle, pseudopregnancy, and pregnancy. Anat. Rec. 48, 65 .

Cole, D. F. (1950) The effect of oestradiol on the rat uterus. F. Endocr. 7, 12.

Davis, J. S. \& Alden, R. H. (1959) Hormonal influence on lipid metabolism of rat uterus. Anat. Rec. $134,725$. 
Dickmann, Z. (1967) Hormonal requirements for the survival of blastocysts in the uterus of the rat. $\mathcal{F}$. Endocr. 37, 455.

Dickmann, Z. (1969) Hormonal requirements for the transformation of morula to blastocyst in the rat: effects of long-term ovariectomy. Steroids, 14, 385.

ELfTMan, H. (1963) Estrogen induced changes in the Golgi apparatus and lipid of the uterine epithelium of the rat in the normal cycle. Anat. Rec. 146, 139.

Fuxe, K. \& Nilsson, O. (1963) The mouse uterine surface epithelium during the oestrous cycle. Anat. Rec. 145, 541 .

Gregoire, A. T., Driscoll, D. H. \& Adams, A. (1967) The appearance of uniformly labelled ${ }^{14}$ Cglucose in rat vaginal fluid and genital tract tissue. F. Reprod. Fert. 14, 313.

Gregoire, A. T., Driscoll, D. H., Adams, A. \& Rakoff, A. E. (1967) Transport of radioactive iodine $\left({ }^{131}\right.$ I) to the vaginal lumen and genital tract of the female rat. Fert. Steril. 18, 303.

HEAP, R. B. (1962) Some chemical constituents of uterine washes: a method of analysis with results from various species. 7. Endocr. 24, 367.

Hechter, O., Krohn, L. \& Harris, J. (1942) Effect of estrogens and other steroids on capillary permeability. Endocrinology, 30, 598.

Hooker, C. W. (1945) A criterion of luteal activity in the mouse. Anat. Rec. 93, 333.

Howard, E. \& De Feo, V. J. (1959) Potassium and sodium content of uterine and seminal vesicle secretions. Am. F. Physiol. 196, 65.

Kopin, I. J. \& WURTman, R. J. (1963) Flow of uterine blood, and the oestrous cycle. Nature, Lond. 199, 386.

Lutwak-Mann, C., Boursnel., J. G. \& Bennett, J. P. (1960) Blastocyst-uterine relationships: uptake of radioactive ions by the early rabbit embryo and its environment. 7 . Reprod. Fert. 1 , 169.

Manery, J. F. (1954) Water and electrolyte metabolism. Physiol. Rev. 34, 334.

Potrs, M. (1966) The attachment phase of ovoimplantation. Am. F. Obstet. Gynec. 96, 1122.

Reynolds, S. R. M. (1949) Physiology of the uterus, p. 297. Hoeber-Harper, New York.

RINGLER, I. (1961) The composition of rat uterine luminal fluid. Endocrinology, 68, 281.

ShelesNyak, M. C. (1960) Nidation of the fertilised ovum. Endeavour, 19, 81.

Williams, M. F. (1948) The vascular architecture of the rat uterus as influenced by estrogen and progesterone. Am. F. Anat. 83, 247.

Younc, A. (1952) Vascular architecture of the rat uterus. Proc. R. Soc. Edinb. B, 64, 292. 